\title{
中国・窑洞住居の庭空間の類型に関する考察 TYPOLOGICAL ANALYSIS OF THE COURTYARD SPACE IN CHINESE CAVE DWELLING
}

\author{
八代克彦*, 茶谷正洋**,八木幸二***, 中澤敏彰**** \\ Katsuhiko YASHIRO, Masahiro CHATANI, Koji YAGI and Toshiaki NAKAZAWA
}

\begin{abstract}
The object of this research is to examine the morphological characteristics of the Chinese cave dwelling (YAO DONG). In order to achieve this, three typological classifications were carried out on the courtyard, as it is one of the spatial characteristics common to Chinese Architecture. Through this analysis it is possible to infer the forms of cave dwellings that have not actually been surveyed yet, and to compare them with other Chinese dwelling types. In conclusion, Chinese cave dwellings can be divided into five distinct types according to form and name of the courtyard space.
\end{abstract}

Keywords : yao-dong, cave dwelling, China, courtyard, typology 窑洞（ヤオトン），穴居，中国，中庭，類型

\section{1. 序 論}

1.1はじめに

窑洞住居は, 中国の黄土高原一帯にみられる穴居で あり，主な生活空間が掘削という原始的手段によって獲 得される横穴であることから特異な住居形式とされてい る。しかしながら, 横穴以外の空間に着目すると, そこ には前庭や中庭などの各種の庭空間が形成されこれら も重要な生活空間よなっている。また, 蕃洞住居の分布 する地域では，いわゆる北京の四合院住宅のような， 院子と呼ばれる中庭をもつ住宅も共存しており, 地域 によっては同一集落内で窑洞住居からこのような地上の 中庭型住宅へと移り住む傾向も認められる。さらに中庭 型住宅についていえば，その規模や建物の配置等の点で 違いがみられるものの，中国全土に分布しており，中国 住宅全般のなかで密洞住居を相対的に理解するうえで も，庭空間を核とする空間構成についての考察は有効な 視点を与えるものと考えられる。

本研究では, 窑洞住居が, 黄土という材料を介し, 庭 空間を核とする空間構成を具現した一住居形式であると の視点に立ち, 現地調査で得た資料に基づき, 窑洞住居 の空間構成の類型を明らかにすることを目的とする。す なわち, 本研究は, 一住居形式の解明にあたり，その住 居の特異性ではなく，それと共存する建築形式との共通 性を分析の対象とすることにより，その住居形式を相対
的に理解しようとするひとつの試みともいえる。

\section{2 既往の研究}

前述したように, 密洞住居は穴居という原始的な住居 であるがゆえに, 十九世紀末から地質学, 人類学等の分 野において研究の端緒が開かれたが，その内容について は紹介的な現地報告”にとよ゙まっていた。建築学の分野 では, 今世紀初頭, 伊東, 関野ら ‘’が中国建築なかんず く宮殿，寺廟，城郭等を主眼とした現地調查を敢行した が, 窑洞住居については，その際に実見した穴居として 簡報されているにすぎない。その後，第二次大戦中に中 国の住宅建築を主題として現地調査を行った吉阪ら ${ }^{31}$ は，華北地方の住居の一類型として窑洞住居をとりあげ 地理学的考察を加えてはいるものの,ここでも蜜洞住居 の穴居と七てのとらえかたは変わらない。

蜜洞住居に関する本格的な調查研究は, 浅井, 張, 王 ら ${ }^{4)}$ による実態調査報告と，八木; 龍ら51による歴史的 考察とに大別できる。前者の実態調査は，近年，中国人 研究者による省区ご亡の詳細な報告什がなれれはいる が, 全体を比較検討するような視点はみられない。また 後者の歴史的考察で, 窑洞住居の祖形とされる古代の穴 居は, 地中に生活空間を求めることでは窑洞住居と共通 するものの, 穴自体の形式や庭空間を介する住居という ことでの接点は見いだし難い。他方，住居の中庭空間を 主題とする研究は, イスラム圏を介するヨーロッパとア
*東京工業大学 技官・工修

** 東京工業大学 教授・工博

**** 東京工業大学 助教授・工博

**** 株式会社 無・設計工房
Technical Assistant, Tokyo Institute of Technology, M. Eng.

Prof., Tokyo Institute of Technology, Dr. Eng.

Assoc. Prof., Tokyo Institute of Technology, Dr. Eng. MU-Sekkei Studio 
ジアから日本の都市住宅の歴史まで含む膨大な蓄積が進 んでいる。このうち中国については, 地理学の分野での 佐藤らの比較研究》があるが, 世界各地の中庭型住宅の 形態上の類似性を，短絡的に文化的伝播と結び付けよう． とする傾向がある。また中国住宅全般の類型化を行った ものに, 劉の平面形状による分類 ${ }^{8}$ や田中の建築構造の 面からの分類 ${ }^{9}$ がある。しかし，両者とも分析対象は建 物部分であり，特に前者では中国各地の住宅を平面形状 によって分類し論するとしながらも，窑洞住居について はそれに従わず，「窑洞式穴居」という，一住居形式の 現地呼称 (窑洞) とその居住形態（穴居）で表現される 特異な類型として扱われている。

\section{3 調查概要}

調查は中国建築学会を通じて1981 年に開始し, 現在 までのところ, 調查地 ${ }^{10} \cdot$ は図一 1 に示す 5 省区に及ぶ。 調査地の選定にあたっては，黄土高原全域を網羅するこ と, また対象集落としては窑洞住居の類型の変遷を解明 するにたる規模と頑型の多様性を有すること，を旨とし たが，ほとんどの窑洞集落が外国人に対して未開放地区 にあり，調查時間が毎回 1 集落あたり数時間という制約 を受けることから，第 1 次の調查において既に継続調査 の必要性を認識した。そこで各調査地の初回は; 住戸レ ベルにおける実態の把握に主眼をおき，徐々に調査範囲 を集落レベルに拡大した。調查内容は実測調查を主体と し，併せて住まい方や施工法についてのビヤリングを 行った。また，継続調査の過程で明らかになったことの ひとうに, 集中豪雨による崖面の崩落や横穴の老朽化さ らに家族の生長や結婚を契機とする家族人数の增加に対
応し,窑洞住居の庭空間の形態が変わることがあげられ， その変容過程については数個所の集落で継続調査中であ る。なお，本稿で分析対象とした蜜洞住居の戸数は計 387 戸であり，その内訳を図一1に示す。

\section{4 研究方法}

窑洞住居は，一般に，ヴォールト状の横穴 1 孔で住戸 を構成することはなく, 矩形の庭の周囲に配された複数 の横穴と外部の塀・建物さらに庭へ至るためのアプロー チ等の集合体として存在する。そこで, 本研究では論を 明確にするために，庭に面した横穴を蜜洞単体と呼び, また庭部分のみを指す場合は, 単に<庭 >, 〈前庭 >, 〈中庭〉とし, 窑洞単体等の周囲に配される要素も含む

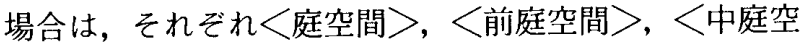
間〉とする。

また，本研究では窑洞住居の庭空間の類型化を行うに あたり，窑洞住居の物的な構成要素を庭，アプローチ， 窑洞単体・塀・建物に 3 分し，それぞれについて考えら れる形態をモデル化する。”さらに，これらのモデルを合 成することにより窑洞住居の庭空間についての毛デル化 を行い，これに対する各地での呼称との対応関係を検討 することにより窑洞住居の類型化を行う。なお，本研究 では類型化の過程において, 中国人研究者のあいだで一 般に用いられる窑洞住居についての分類法，すなわち主 に地形亡の関係による分類法を援用するものとするが， こうした類型化の手法をとることにより，窑洞住居の変 容過程で現れる形態や，制約のある調査において確認す ることのできない形態についても考慮したうえで，中国 側の類型を再定義するごとが可能となると考える。

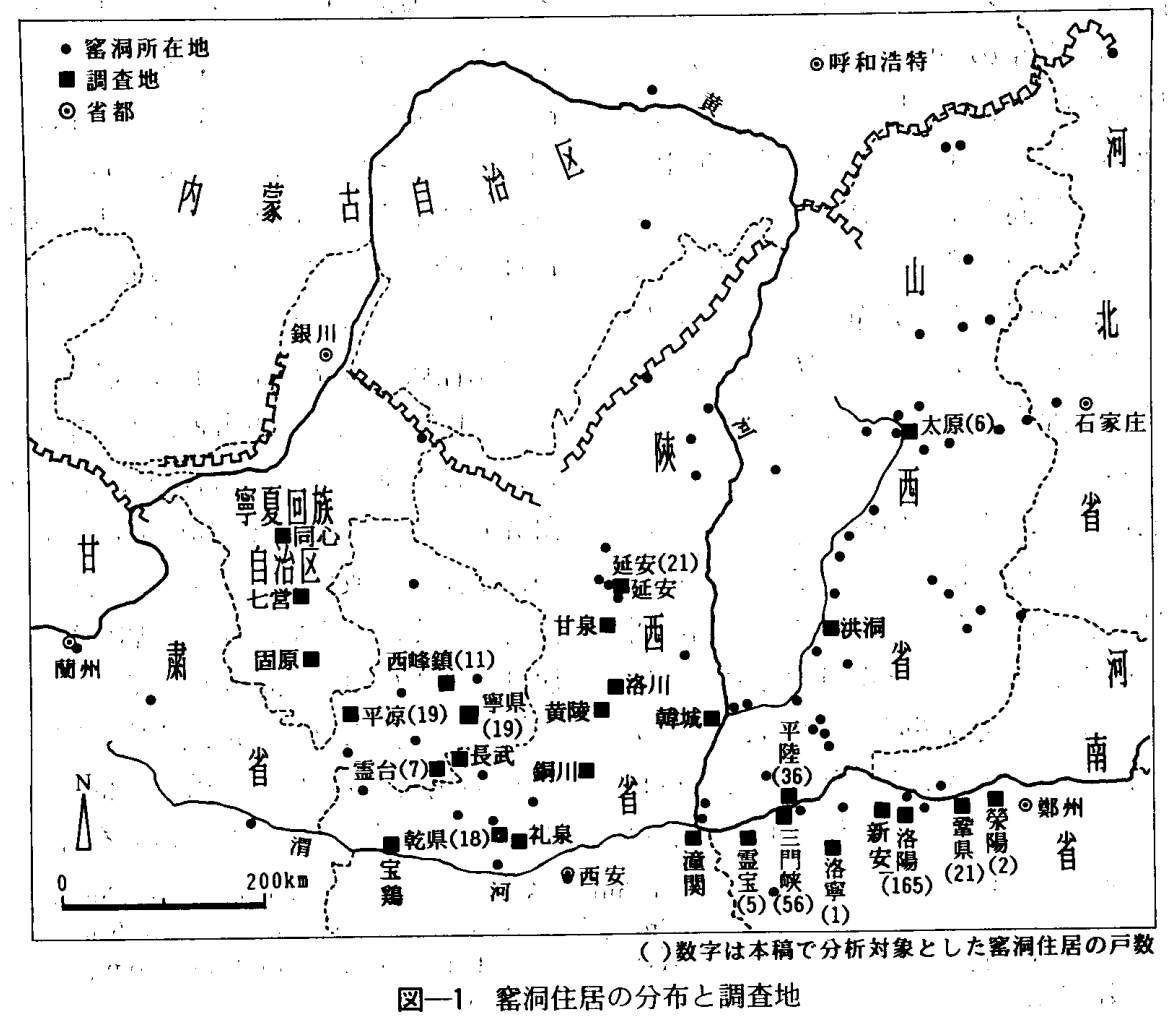




\section{2. 中国人研究者による窑洞住居の分類}

本章では, 実測調査した事例を引きつつ, 中国人研究 者による窑洞住居の分類"'について述べる。

図一2は，切り立った黄土崖面を利用して窑洞単体を 穿った例であり，2 孔の窑洞単体の前方に，2棟の建物 と塀とで細長い中庭を形成している。このように，山の 斜面や崖面に篚すなわちもたれかかるように造られた 窑洞住居は, 篚崖式または靠山式と呼ばれている。

図一 3 の延安の例は，地形条件からいえば，山の斜面 を切り崩し庭空間を獲得していることから靠山式とみな せるが，窑洞単体のつくり方は掘削のみによらず，次の ような方法がとられる。山の斜面に庭空間をつくる際, 密洞単体之同規模同形状の土塊を必要な数掘り残し，こ れを型枠として石積みし上部を土で固めた後, 型枠と なった土塊を掘り出す。同地区ではこれを石蓄と呼び， 掘削のみによる窑洞単体 (圭蓄) と区別している。組

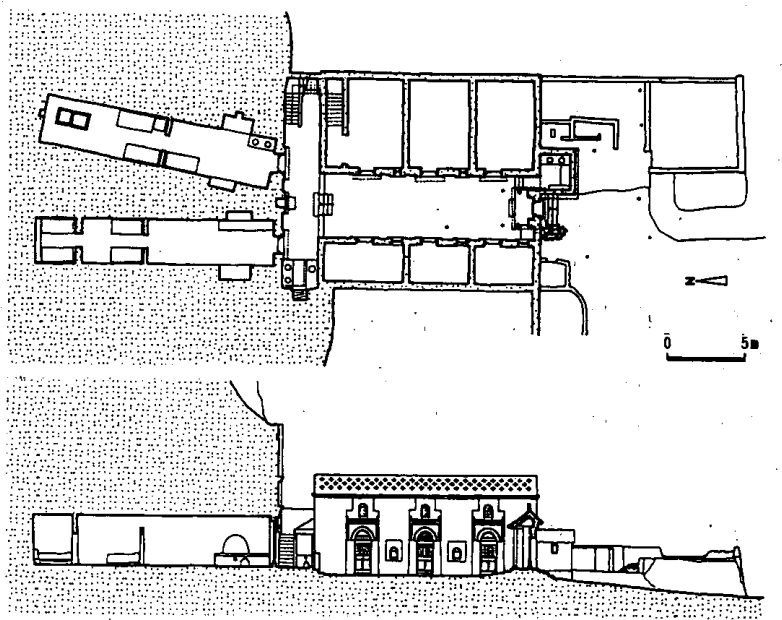

図一2 実例 (河南省竬県)


图一3実例，(陝西省延安)
積造の窑洞単体は平坦地でも建設可能であり，寧夏回族 自治区 (図一4), 甘肃省，山西省，河南省では，石のほ かに日乾煉瓦 ( ものもみられ，土坏拱蓄，磚錨蓄 ${ }^{21}$ などと俗称される。 また中国人研究者は，このような平坦地に建設される形 式を独立式あるいは地”上窑洞之呼ぶが，本研究で は，それが組積造の窑洞単体を主に指し示すことから， 以下では，平坦地に組積作業のみにより造られる蜜洞単 体を, 地上窑と呼ぶ。

図一5は，塬と呼ばれる黄土台地に矩形の竪穴を掘 削し，これを中庭として四方の崖面に窑洞単体を穿った 例であり，居住空間全体を地下に沈めたことから梁沙 式 ${ }^{131}$ と呼ばれる。下沈式では，中庭への昇降に階段また は斜路形式のアプローチが用いられる。図一5では，斜 路形式のアプローチを, 南面東側の窑洞単体に接続して おり，これを中庭から見た場合，他の窑洞単体と同様の 立面となっている。

図一6では，前院 (前庭)，染院 (作業場)， 天井院（前庭に比べてプライベートな中庭）上呼 ばれる機能の異なる 3 つの庭空間が形成されでおり，そ れぞれ地形との関係から,前院と雑院については靠崖式, 天井院は下沈式の庭空間と見なすことができる。ゆえに，

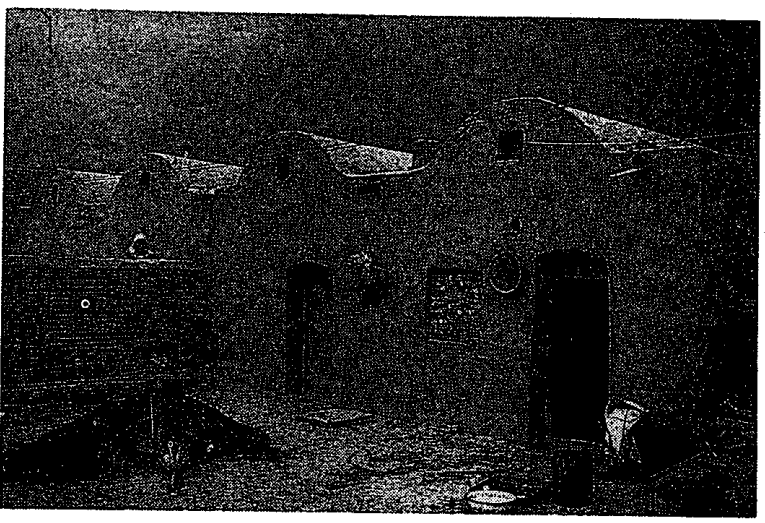

図一4 実例（寧夏回族自治区同心）
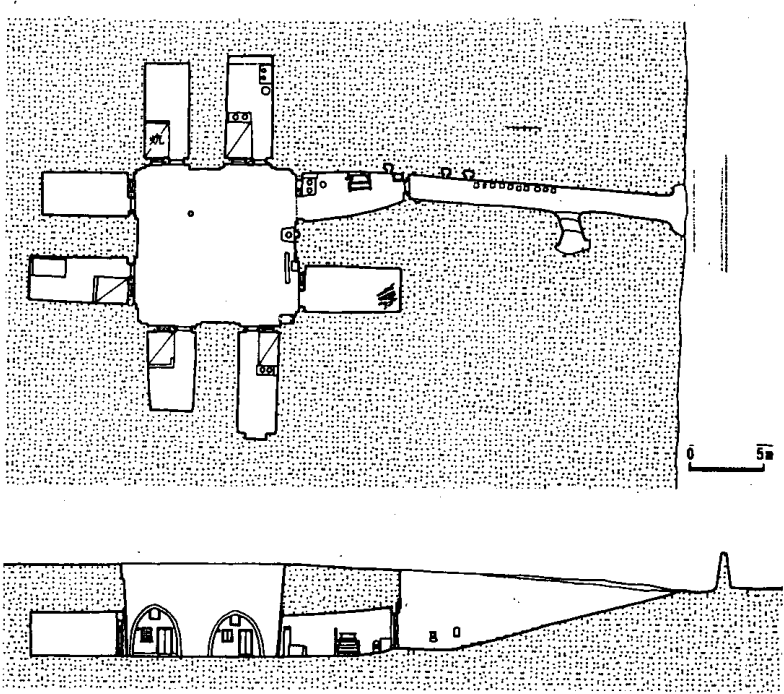

図一5 実例（陝西省乾県） 
この例は靠崖・下沈の混合形式といえる。このほかにも， 庭の組み合わせの例として, 複数の下沈式の中庭を地下 で連結したものや，大規模な下沈式の中庭を土塀で仕切 り，数家族で所有する例などがみられる。

\section{3. 窑洞住居の構成要素のモデル化}

\section{1 庭のモデル化（図一7）}

窑洞住居の庭を 4 立面と地面とによって構成された升 型の空間とみなし，この升型の空間の平・断面を，以下 のように分類する。

平面については，窑洞単体を掘削可能な崖面の数（以 下，崖面数とする)により, 図一7に示すように，崖面 数 0〜4に分類する。なお，図一4のような地上密の場 合は崖面数 0 となる。

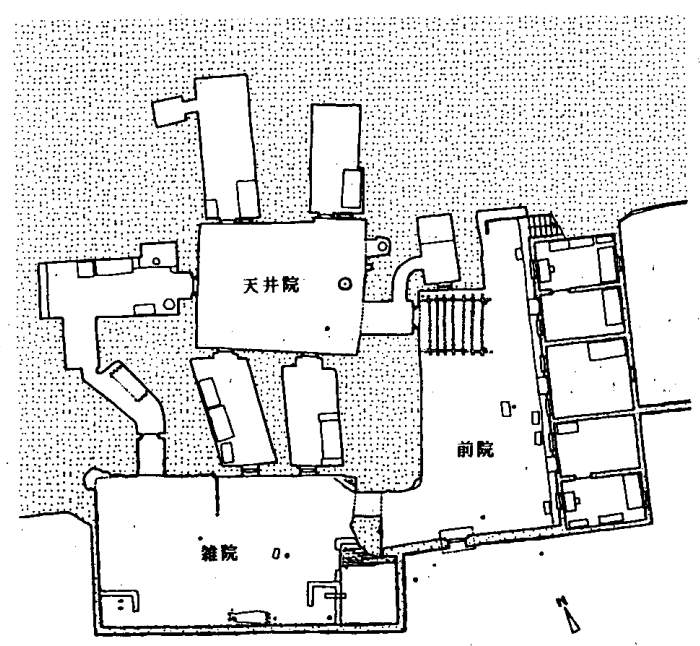

図一6 実例（河南省滎陽）

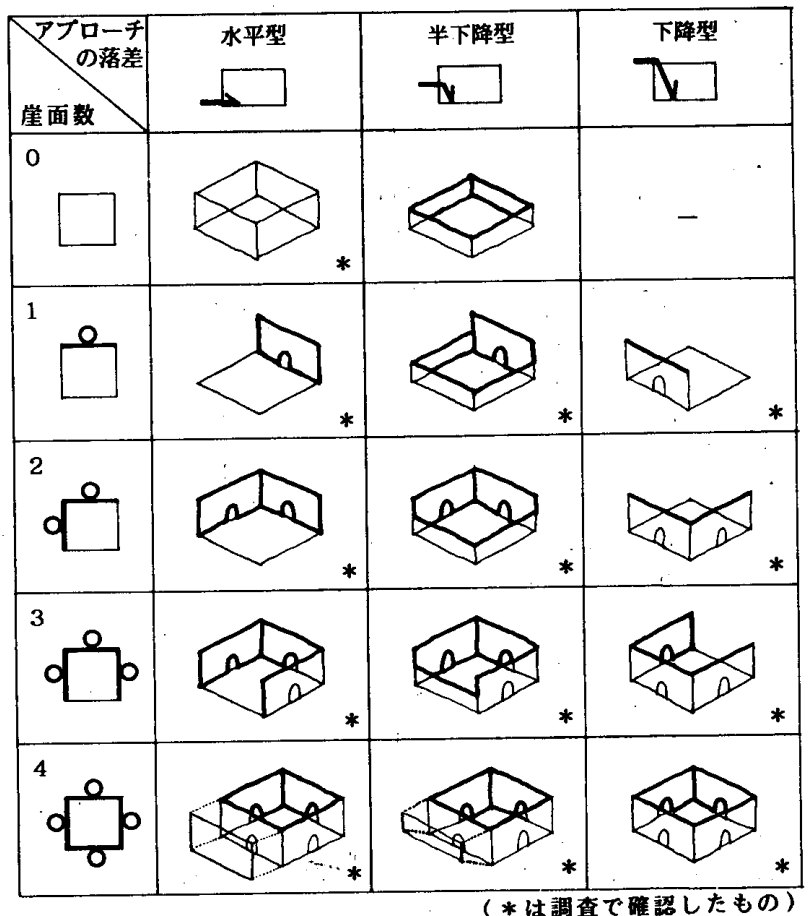

図一7庭のモデル化
断面については，庭へ至るアプローチの落差を指標と し(図一7), 水平型, 下降型, 半下降型に分類した。

窑洞住居の庭とアプローチの数の対応関係は,一般に， ひとつの庭を 1 家族が所有するため，1 庭 1 アプローチ が基本となるが，図一8 の例では，血縁関係のない 2 家 族がひとつの庭に住むため, 庭を土垪で 3 つに仕切り， このうちアプローチを降りてすぐの庭空間を物置や畜舎

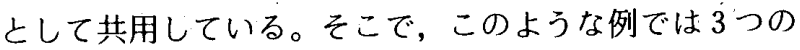
庭をまとめで, ひとつの庭として扱った。

平断面の組み合わせから，考えられる庭の形態を図一 7 に示す。図中，調査で確認されたものに*を付す。図 一7において，いわゆる下沈式の庭は崖面数 4 に対応す る。

3.2 アプローチのモデル化（図一9)

前節で求めた庭のモデルのうち，水平型かつ崖面数 0 〜3のものについては，一般に庭と外部との境界を塀で 仕切り，その一角に大癸門を配するか，あるいは図一3の 例のように，塀もなく庭に直接進入するのに対し，それ 以外のものについては掘削作業によって斜路やトンネル が形成される。本節では，後者の場合，すなわちある長 さを有するアプローチについて，考えられる形態を示す。

アプローチの指標として, 前節で用いたアプローチの 落差 (水平型, 下降型, 半下降型) のほかに, 庭との位 置関係に着目し，庭内型，庭外型，中間型に分類した。 庭外型についてはさらに断面形状によって庭外溝型と庭 外トンネル型とした。これらの組み合わせから，考えら れるアプローチの形態を図一9に示す。

図一 9 より; 図一5 は庭外トンネル・下降型となる。 また図一10はアプローチを中庭の崖面に沿わせた例で

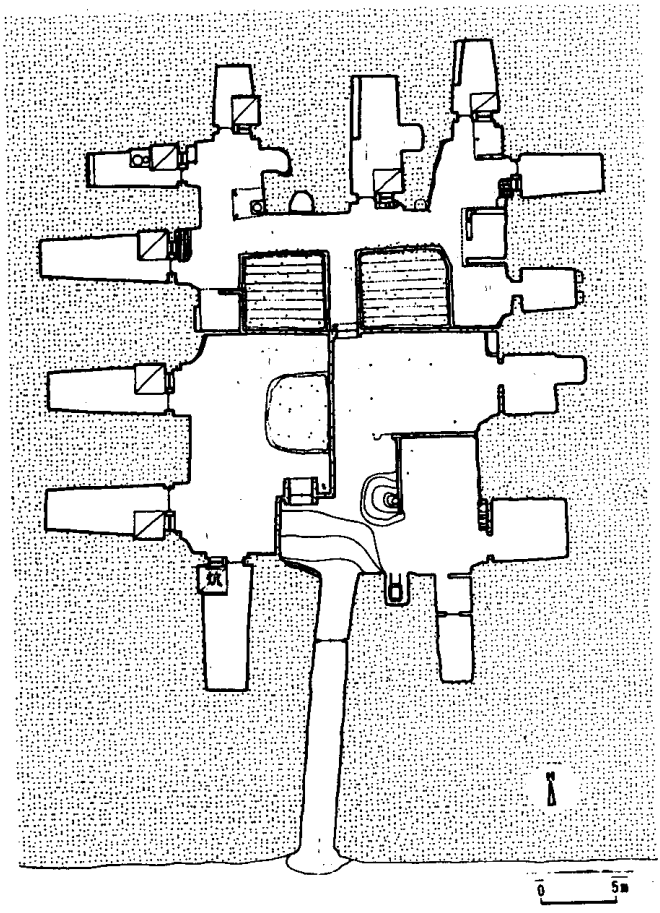

图一8 実例（甘肃省平凉） 
あり，庭内・下降型となる。図一11では，アプローチ を庭内外のレベル差の小さい西側に配し，中庭へ出る手 前をトンネル形式としていることから庭外トンネル・半 下降型となる。

図一12 は, 1981 年調查時において庭外溝・半下降型 のアプローチを有する下沈式であるが, 元来のアプロー チは庭外トンネル・下降型であったという。同地区では 市街化が急激に進行しており, 1984 年調査時には, 窑 洞単体を取り壊した後に家屋を建設する例が多く, 図一 12 の例もやがてはアプローチ両脇の窑洞単体を取り壊 してその跡に土塀を築き，これにともないアプローチも 庭内・半下降型へと変化することが予想される。これま での調查で,このようなアプローチの経年的な変化が多
く確認されたが，そのほかに，周辺の生活道路とのかね あいから新たなアプローチを建設する例もみられた。

3.3 平面構成のモデル化（図一13）

本章第 1 節の庭のモデル化（図一7）では，窑洞単体 を崖面数によって地上窑（崖面数0）と掘削によるもの （崖面数 1〜4）とに分けたが, 本節では窑洞単体・建 物・塀の組み合わせによる平面構成を考察することが目 的であり，またここれまでの調查で地上窑と掘削による 窑洞単体が併存して住戸を形成する例がほとんどないこ とから,これらを一括し, 窑洞単体がある面の数（以下， 窑面数とする)によって窑面数 1 - 4 とする。

さらに，窑洞住居以外の中国の住宅との平面構成の比 較を可能にする指標として, 居住部分 (窑洞または建物)

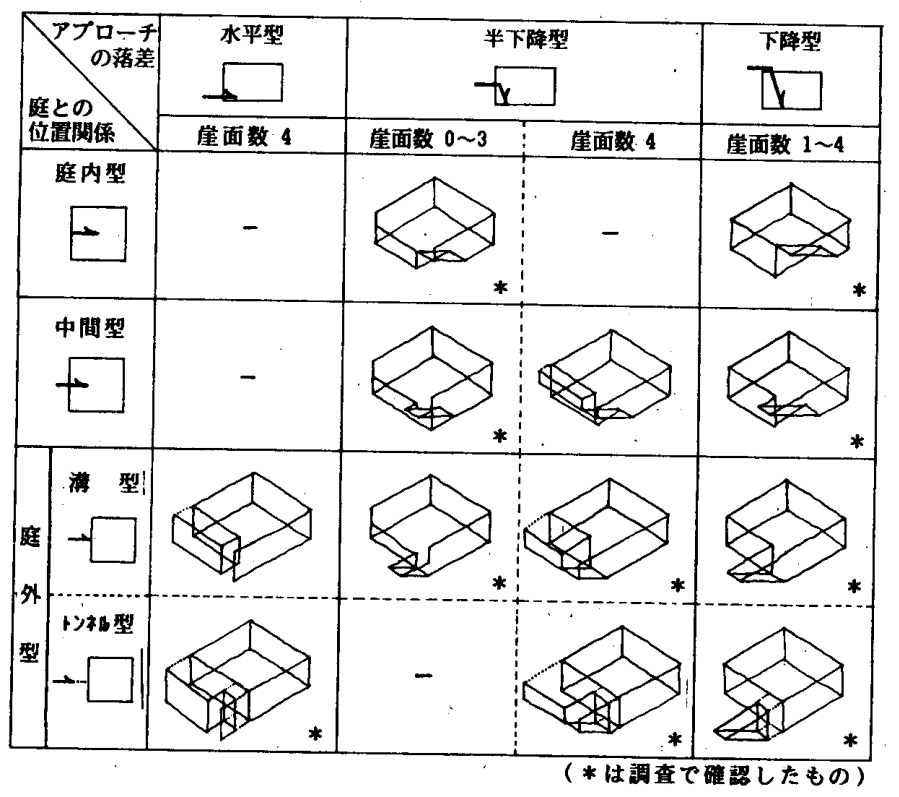

図-9 アプローチのモデル化
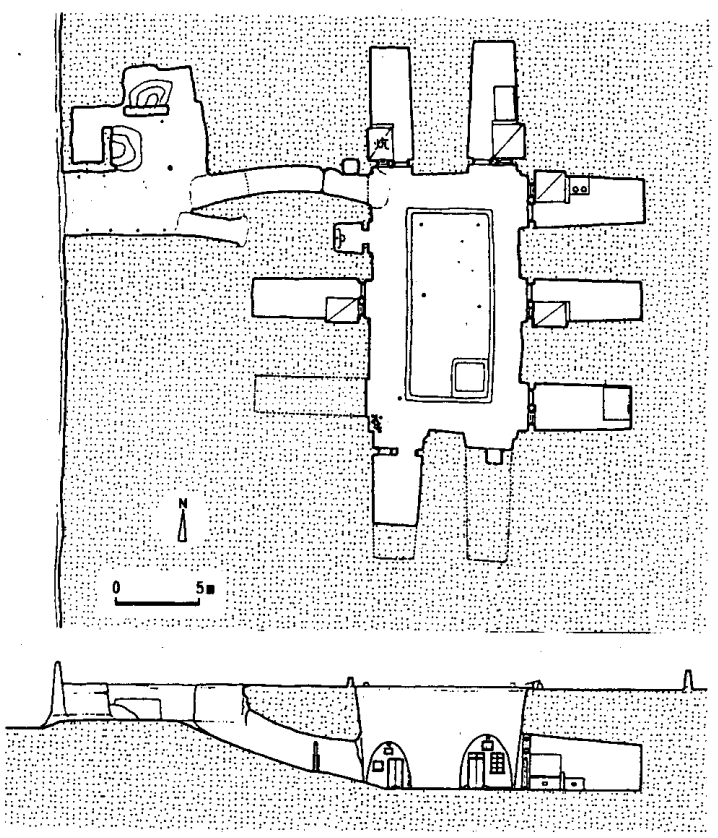

图-11実例（甘肃省西峰鎮）

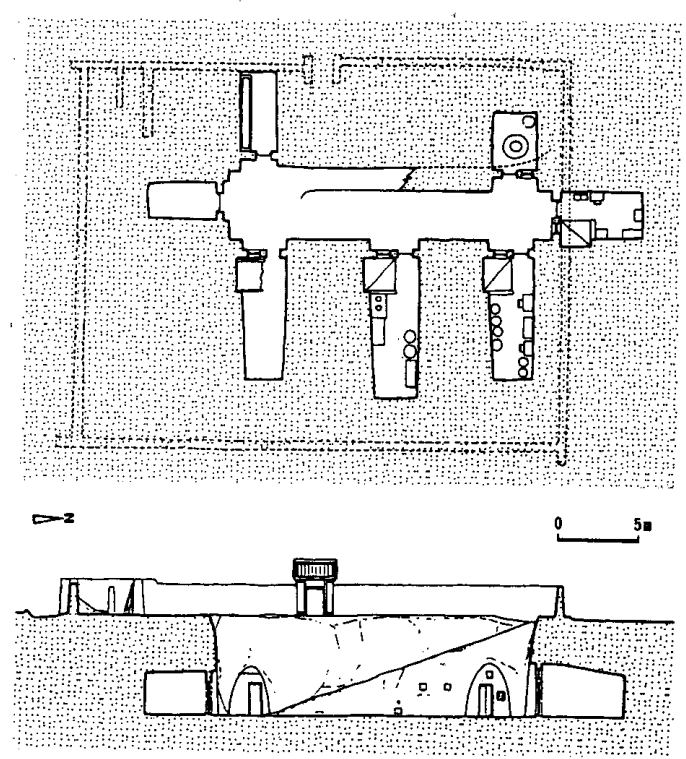

图一10 実例（甘肃省霊台）
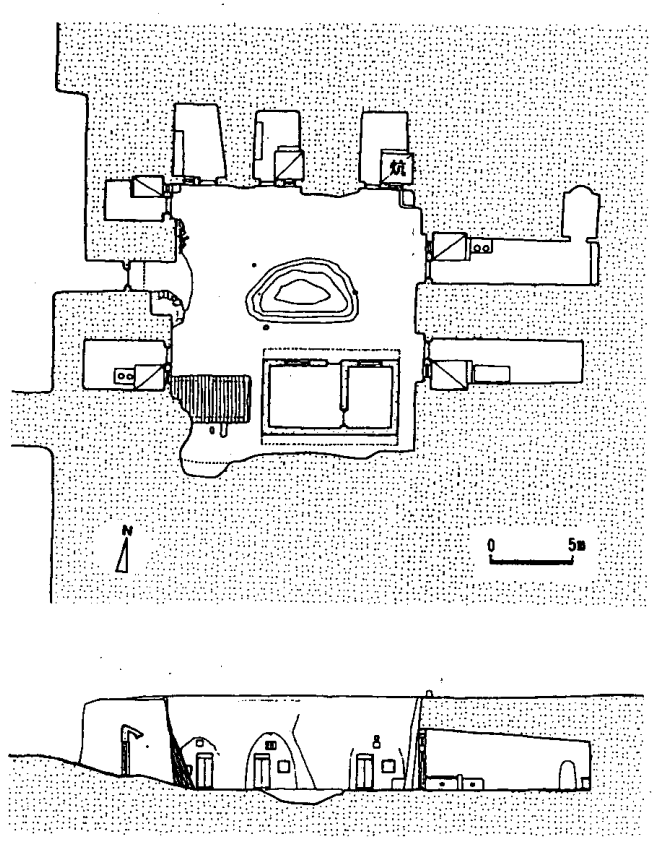

图-12 実例 (甘肃省西峰鎮) 
に，また庭が閉鎖型か非閉鎖型かをみるための指標とし て, 窑洞単体以外の庭の囲い（建物または塀）に着目し， それらの面の数（以下，それぞれ居住面数，囲心面数と する)より，居住面数 $1 \sim 4$, 囲い面数 0 - 3 に分類した。 なお， 1 面に窑洞単体・建物・塀のうち二者以上が存在 する場合，居住空間を重視し，窑洞単体・建物・塀の順 に従い，1面にひとつの要素が存在するものとした。図 -13 に, 平面構成のモデルを示す。

居住面数は, 劉による中国の住宅全般の平面類型では, 居住面数 1 が横長方形, 居住面数 2 が曲尺形, 居住面数 3 が三合院，居住面数 4 が四合院にそれぞれ対応する。 前章の図一 2 を例にとると；庭の.3 面に居住部分がある ことから，窑面数 1 の三合院型となる。放

窑洞住居の庭空間は, 窑面数と囲い面数の和により, 閉鎖型（和が 4 ，図中の枠内）と非閉鎖型（和が 3 以下） に分けられる。調查範囲では，ほとんどの例が閉鎖型で あり，非閉鎖型は図一-3のような山間部の急峻な斜面を 利用した，いわゆる靠崖式に多くみられる。しかしなが ら非閉鎖型のものでも図一3のように，庭の側方および 前方に掘り残しの土塊や崖が存在し，これらによって庭 としての領域を明確にしている。したがって，非閉鎖型 でも地形を利用することで閉鎖型に準ずる庭空間を形成 していると考えられる。

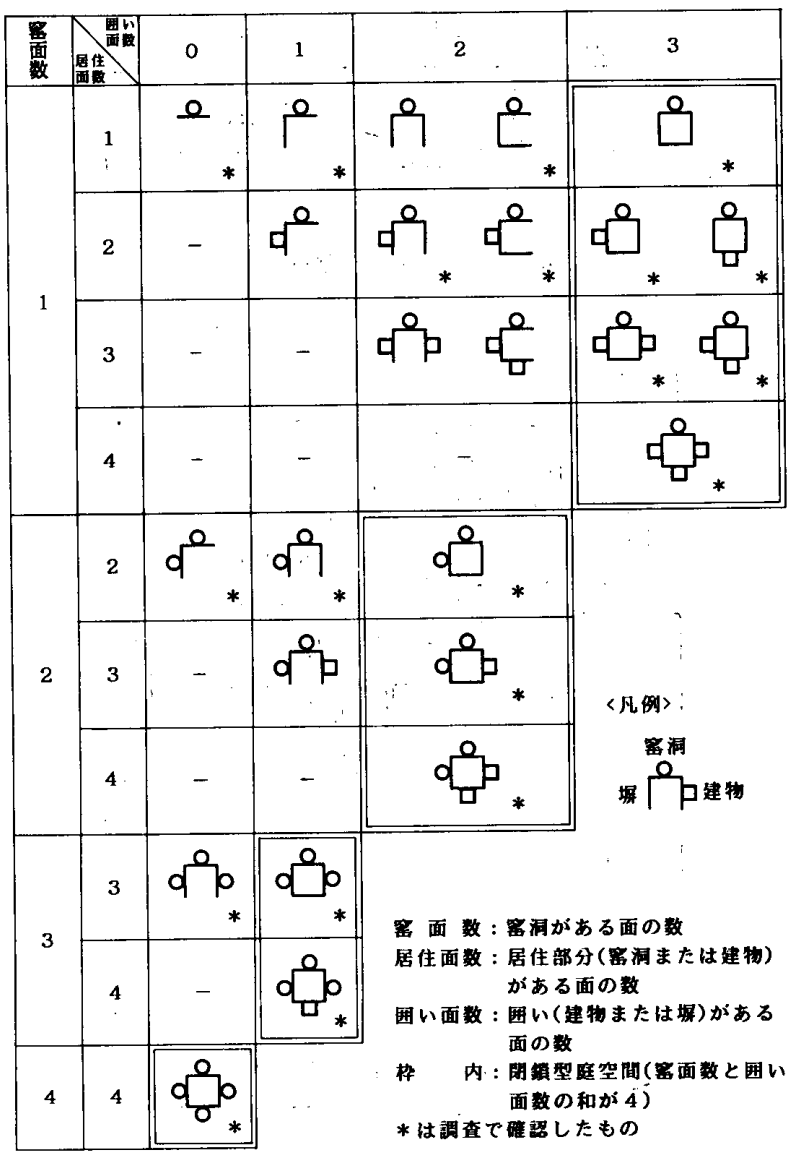

図一13 平面構成のモデル化

\section{4: 輁洞住居の類型化}

4.1 庭空間のモデル化と呼称との対応関係

表一 $1^{14}$ に，庭空間に対する各地での呼称を蜜洞単体, 庭, 庭空間に分けて示す。表一1より, 窑洞単体, 庭, 庭空間に対する呼称の語尾には,それぞれ䆺(窑洞単体), 院 (院子すなわち中庭), 庄 (生子すなわち田舎の大邸宅) が用いられる場合が多く, 中庭または中庭空間の形態は 語幹に相当する部分によって写実的に表現される。そこ で,語幹の部分が指示する形態について考察するだめに， 前章で求めた庭 (図一7)・アプローチ（図一9）・平面構 成（図一13）のモデルを合成することによって庭空間の モデル化を行い，併せて，表一1の各地の呼称との対応 関係を図一14に示した。なお，図一14では，アプロー チとして庭外型を用い，かつ，窑洞住居を構成する要素 のうち建物を省略した表現としている。以下，図一14 をもとに考察する。

黄土高原の中西部で用いられる明庄（子), 明窑 (院) は, 暗庄（子）と対比する呼称であり，前二者が，後者 すなわち下沈式の庭空間に比へ，開放的で，かつ，庭に 溜まった雨水の排出も容易であることから，心理的にも 明るい庭空間であることがうかがわれる。また，両者の， 中間的な性格の庭空間を表す呼称として半明半暗庄(子) があるが，これは半地下の庭空間を指すものである。

出水 (窑) 院は, 黄土高原では最も降雨量の多い南東 部の洛陽で用いられる呼称である。出水という表現は， 同地区の天井 (窑) 院と呼ばれる下沈式の庭の 1 面を塀 に置き換えた場合，中庭から外部への排水が容易である ことを明示したものである。また同地区の筑箕蜜は，穀 物や粐款をふるいに分ける農具（箥箕）の形態を借りて

表一1 庭空間に対する各地での呼称

\begin{tabular}{|c|c|c|c|}
\hline सx & 密洞単体 & 庭 & 庭空間 \\
\hline 察 & 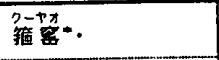 & & \\
\hline 更 & \multirow{2}{*}{ 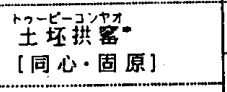 } & & \\
\hline 甘 & & 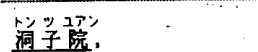 & 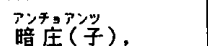 \\
\hline \multirow{2}{*}{ 㙌 } & $\vdots$ & (地)坑院 & 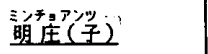 \\
\hline & 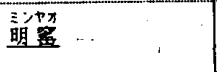 & 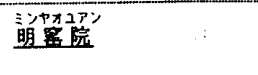 & 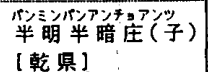 \\
\hline 傸 & 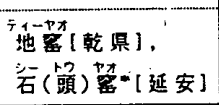 & 空㿾院 &  \\
\hline $\begin{array}{l}\text { 山 } \\
\text { 西 }\end{array}$ & 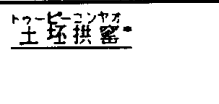 &  & \\
\hline 河 & 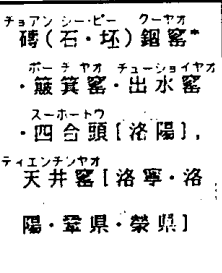 & 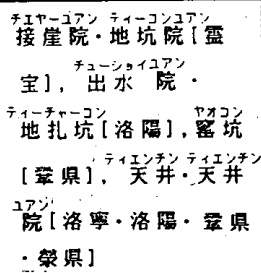 & 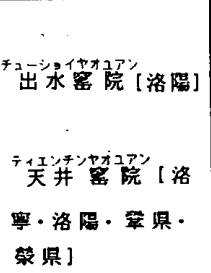 \\
\hline
\end{tabular}


窑洞単体が庭の三方向にあるごとを，四合頭とは四方に あることをそれぞれ指し示している。

下沈式の庭空間に対しては, 各地において様々な呼称 があるが，その性格はふたつに大別できる。ひとつは主 に黄土高原の中西部で用いられ，洞子(洞穴) ・下挖 (下 方に掘ること）・地坑（土地の䆶み）・地窑（地下の窑洞 単体) ・地害(地下室) ・地陰(地下で暗いこと)・地泥(地 下で泥で覆われていること）・地扎（窑洞単体が地下に 潜り込むこと）・复坑（窑洞単体が穿たれた竪坑）など の表現によって，生活空間全体が地下にあること，すな わち居住者の庭空間を見下ろす視線がうかがわれる。

一方, 黄土高原の南東部にあたる河南省では，下沈式 の庭空間に対する一般的な呼称として天井（窑）院があ げられる。これは地下の中庭から真上を見上げたとき， 4 崖面のパースペクティヴ効果によって天が四角く切り 取られる状況を表していると考えられ，このような状況 が成立するアプローチの形態として，中庭上部の矩形が アプローチによって久落することのない形態，すなわち 庭外トンネル型が対応すると考えられる。

次に, 庭空間の呼称について, 窑洞住居と中国住宅全 般とでの地域的な対応関係をみると，中国住宅で用いら れるく院子>は, 窑洞住居においても閉鎖型庭空間に対 して黄土高原のほぼ全域で通用するが, 南方系住宅で用 いられる，スカイライト的機能を有する比較的小規模な 中庭の呼称であるく天井>は, 地域的には黄土高原の南 東部の下沈式の庭空間に限定して用いられる。

\section{2 窑洞住居の類型化}

前節までの考察結果をもとに, 窑洞住居を, 靠崖式, 準靠崖式, 下沈式, 準下沈式, 地上式の 5 類型に分類し, 表一2に示すように，それぞれを庭およびアプローチの 形態, 平面構成 (劉による類型との対応), 庭空間の呼

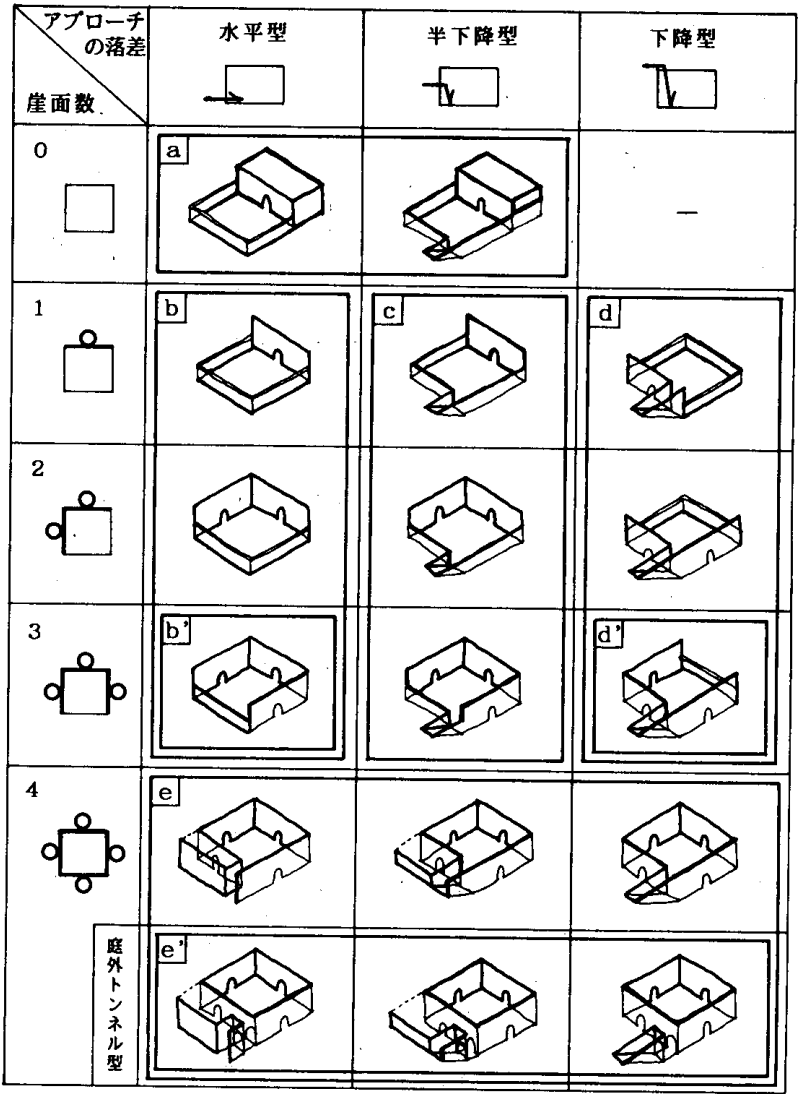

a

籍篦 [蜜夏]





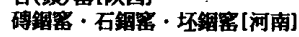

b

琞底(子) [甘萧]

明䈍(院) [甘肃・傸西 $]$

接原院[河南]

c

半明半暗庄(子)[甘肃・凝西 $]$
回团

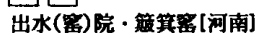

e

洞子院 - (地)坑院 - 暗庄(子)[甘肃]

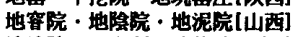


e]

天井・天井(富)院[问南] 地楆・下挖院・地坑察庄!陕西]

図一14庭空間のモデル化

表一2 窑洞住居の類型の定義

\begin{tabular}{|c|c|c|c|c|c|c|}
\hline \multirow{2}{*}{ 類型 } & \multicolumn{2}{|c|}{ 庭の形態 } & アプローチの形態 & \multirow{2}{*}{  } & \multirow{2}{*}{ 庭空間の㭔称 } & \multirow{2}{*}{$\begin{array}{l}\text { 調查 } \\
\text { 事例 }\end{array}$} \\
\hline & 崖面数 & 落差 & 庭との位置関係 & & & \\
\hline 靠山式 & $1-3$ & 水平型 & - & $\begin{array}{l}\text { 横長方形, 曲尺形 } \\
\text { 三合院,四合院 }\end{array}$ &  & $\begin{array}{l}\text { 目 } 2 \\
\text { 国 } 3\end{array}$ \\
\hline 準靠山式 & $1-3$ & 下降 型 & 庭内型, 中間型, 庭外型 & （同上） & (同上) & 図15 \\
\hline \multirow{3}{*}{ 下 沈 式 } & \multirow{3}{*}{4} & 水 平 型 & 庭外型 & \multirow{3}{*}{ 四合院 } & \multirow{3}{*}{ 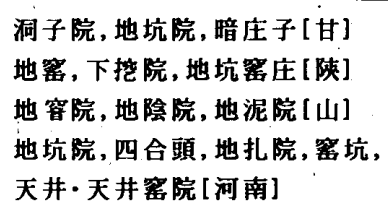 } & \multirow{3}{*}{ 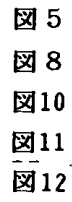 } \\
\hline & & 半下降型 & 中間型, 庭外型 & & & \\
\hline & & 下降 型 & 庭内型, 中間型,庭外型 & & & \\
\hline 準下沈式 & $1-3$ & 半下降型 & 庭内型, 中間型,庭外算型 & $\begin{array}{l}\text { 兴辰方形,曲尺形 } \\
\text { 三合院,四合院 }\end{array}$ & 半明半暗庄子[甘·陕] & 図16 \\
\hline \multirow{2}{*}{ 地 上式 } & \multirow{2}{*}{0} & 水 平 型 & - & \multirow{2}{*}{ (同上) } & 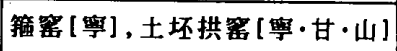 & \multirow{2}{*}{ 図 4} \\
\hline & & 半下降型 & 庭内型, 中間型,庭外漊型 & & 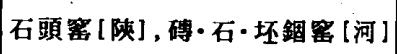 & \\
\hline
\end{tabular}



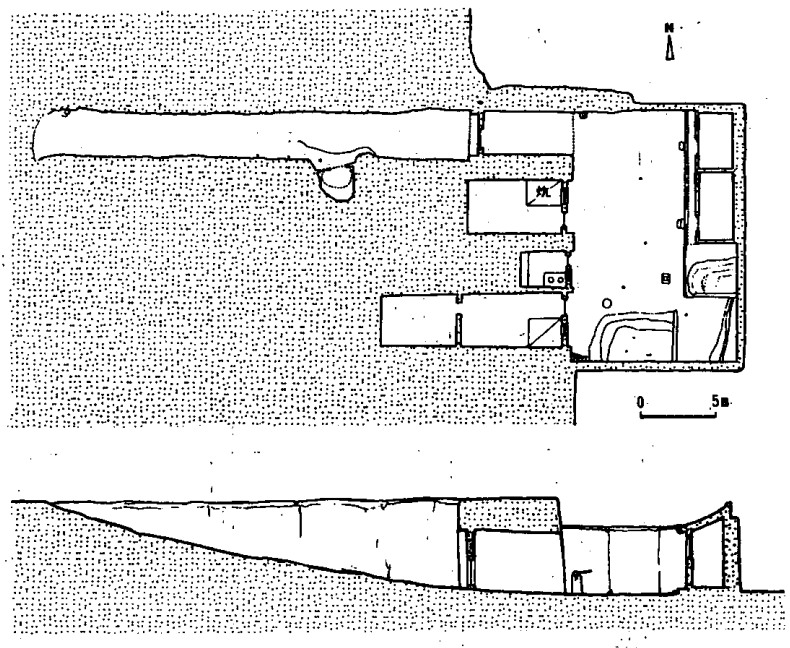

图一15実例（陝西省乾県）
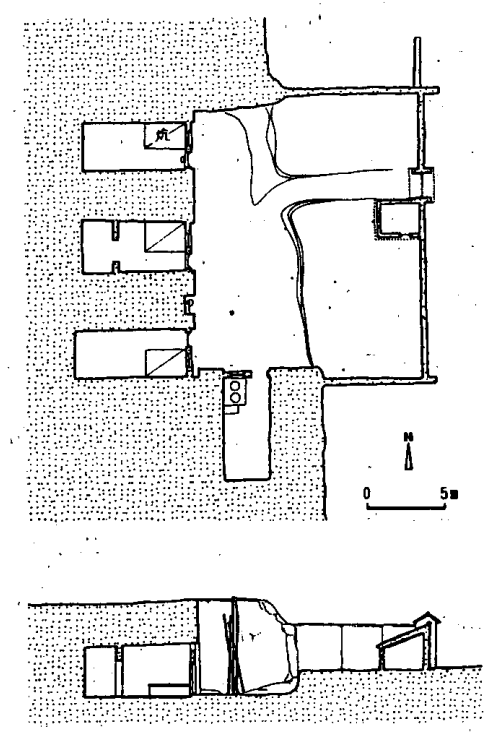

図一16 実例（陝西省乾県）

称との対応関係によって定義した。なお，準靠崖式，準 下沈式については, 図一15, 図一16に実例を示す。

\section{5. 結 論}

本稿では，穴居という特異な住居形式として扱われて きた窑洞住居を，中国住宅全般にわたる特徴のひとつで ある庭空間を核とする空間構成に着目し，その形態的な 特徴を明らかにしつつ類型化を行った。類型化の手法と して, まず庭, アプローチ,'平面構成についてのモデル を求め,さらに，それらを合成することによって庭空間 をモデル化し，これと各地での呼称との対応関係を考察 することにより，中国人研究者による窑洞住居の分類を， 靠崖式, 準靠崖式, 下沈式, 準下沈式, 地上式として再 定義した。また，類型化の過程において，窑洞住居は閉 鎖型庭空間を形成する傾向があること，また南方系住宅 で用いられる中庭の呼称 <天井>が, 黄士高原南東部の 下沈式の一類型に対応することを示した。

なお，今後の課題として；本稿で求めた窑洞住居の庭
空間のモデルを用い, 各地の窑洞集落の変容過程および その地域的な特性について考察することがあげられる。

注

1) Richthofen, F.v. : CHINA (Ergebnisse eigener Reisen und darauf gegründeter Studien), Berlin, pp. $56 \sim 74$, 1877. 邦訳に，佐藤晴生訳：北支那の黄土に就いて(上), 蒙古 1, pp. 155 177, 1939

大原里賢：支删人穴居，模様, 東京人類学会雑誌, Vol. 4, No. 32, pp. 34 35, 1988 年 10 月.

坪井正五郎: 支那人の横穴住居, 東京人類学会雑誌, Vol. 6, No. 64, pp. 340 345, 1891 年 7 月

2) 伊東忠太: 支那印度土其耳旅行談, 建筑雑誌, Vol. 19, No. 240, pp. $774 \sim 798,1906$ 年 10 月または, 伊東忠 太：見学紀行, 龍吟社, pp. 169 184, 1944 年 関野 賁：支删の穴居，要東, Vol. 5 , No. 2, pp. 1 6, 1928 年 または, 関野 貞：支那の建築と芸術; 岩波書 店, pp. 395 400, 1938 年

3）吉阪隆正：北支蒙腲に於ける住居地理学的考察（1940年 早稲田大学卒業論文), 収録は, 吉阪隆正集 1 - 住居の発 見, 勁草書房, pp. 1 - 87, 1984 年 十代田三郎：北支・蒙揋の住居建築の構造調查報告, 建 築雑誌, Vol. 55, No. 675, pp. $426 \sim 436, . .1941$ 年 6 月

4）: 贱井新一, 大前岩八：支那の穴居; 建築雑誌, Vol. 56 , No. 682, pp. $67 \sim 84,1942$ 年 2 月

張歩騫, 傳高傑, 杜修坞 (建築理論及歴史研究室 南京 分室)：河南密洞式住宅，未刊，1958 年 10 月

王琈：陝西宝䳕地区士密洞調查報告，未刊，1965 年 7 月 および，陝西省窑洞建築調查報告，末刊，1965 年 11 月

5）八木奖三郎：支那住宅志, 南満州鉄道株式会社, 1932 年 龍非了: 穴居雑放, 中国營造学社異刊, 第 5 巻, 第 1 期, pp. 55 76, 1934 年 9 月

6） 省区ごとの調查報告をまとめたものに，

侯継堯, 任致遠, 周培南, 李傅澤: 窑洞民居, 中国建築 工業出版社, 1989 年

7）佐藤甚次郎：世界における中庭式閉鎖型屋䑤構の分布と その系譜, 日本女子大学文学部紀要 $20, p p .65 \sim 98$, 1971 年

須藤 賢：閉鎖屋敷に関する二三の歴史地理学的研究， 新潟大学教育学部紀要, Vol. 1, No. 1, pp.41 48, 1959 年

8) 劉敦植：中国住宅概説, 建築工程出版社, 1957 年 邦訳に, 田中 谈, 沢谷昭次訳：中国の住宅, 鹿島出版社, 1976 年

9)田中 淡: 中国住宅の類型, 日本の住まいの源流/日本 基層文化の探求，文化出版局，pp. $343 \sim 370 ， 1984$ 年

10） 1986 年から 2 年間, 八代克彦が中国政府給付奖学生とし て西安冶金建築学院に留学し, 西安, 洛陽近郊にて単独 調查を行った。調查地の詳細についでは, 青木志郎ほか : 民家集落の建築類型学的考察・中国黄河流域の蜜洞式 民家考察, (財) 新住宅普及会・住宅建築研究所, pp. 25 一 26, 1988 年

11）前揭書・注 6) pp. 22 40

12）寧夏回族自治区では，日乾煉瓦積みの地上密を土坏拱密

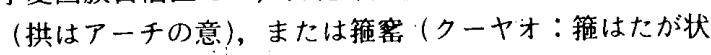
の物の意，すなわちアーチ形状を表すと考えられる）と 
呼ぶ。甘肃省では土坏拱窑が一般的であり，陝西省では 石窑を石頭密 (シートウヤオ) とも呼ぶ。河南省では使 用材料によって磚銅蜜, 石銦蜜, 坏銅蜜と呼ぶ。錮 (クー) は金属を溶かして隙間をふさぐこと，あるいは閉じ込め ることの意で, ヴォールト状の窑洞単体が焼成煉瓦 (磚) などで覆い固められていることを表すと考えられる。

13）中国語では下沉式と記す。<沈〉は，〈潘>の簡体字で あり，またく沉 (日本語の沈むの意) >の異体字である。
本研究では日本語で沈むを表すく沈〉を正字である く沉〉のかわりに用いる。

14）表一1の下線部は，主に前揭書・注 3）および，任致遠： 下沈式黄土窑洞民居院落雊議, 建築師 15, pp. 75 82, 1983 年 6 月による。

(1991 年 6 月 10 日原稿受理, 1992 年 2 月 4 日採用決定) 